How to cite this work: Parreño Castellano, J.M., Domínguez Mujica, J., Armengol Martín, M. T., Boldú Hernández, J., \& Pérez García, T. (2019). Real estate dispossession and evictions in Spain: a theoretical geographical approach. Boletín de la Asociación de Geógrafos Españoles, 80, 2602, 1-25. http://dx.doi.org/10.21138/bage.2602

\title{
Real estate dispossession and evictions in Spain: a theoretical geographical approach
}

Desposesión inmobiliaria y desahucio: una aproximación geográfica teórica

\author{
Juan Manuel Parreño Castellano \\ juan.parreno@ulpgc.es \\ Josefina Domínguez Mujica \\ josefina.dominguezmujica@ulpgc.es \\ Matilde Teresa Armengol Martín \\ matilde.armengo|@ulpgc.es \\ Jordi Boldú Hernández \\ matilde.armengo|@ulpgc.es \\ Tanausú Pérez García \\ tanausupg@gmail.com \\ Departamento de Geografía \\ Universidad de Las Palmas de Gran Canaria (España)
}

\begin{abstract}
The recent economic crisis in Spain has revealed the weakness of a real estate model based on an over-indebtedness that was upheld and promoted by the financial and political system. As the foundations of this system began to crumble, the socioeconomic consequences soon started to show; among them, a rise in evictions and foreclosures that is particularly relevant to the field of Geography. This paper has two main goals: First, to provide a theoretical reflection on the state of affairs in real estate dispossession and eviction in the context of both the Spanish crisis and the
\end{abstract}


global trend towards the financialization of the world economy; and second, to offer a methodological interpretation based on a new study source, namely, the proceedings filed in the Centralized Service of Process and Attachments Offices of judicial districts, which allow to examine how the above mentioned phenomena translate in spatial terms. The results of the study emphasize the structural character of dispossession through legal action in our country's secondary accumulation system as well as the need to move forward in the use of judicial records by means of a correct interpretation of proceedings and through the refining of the geographical information.

Key words: evictions; foreclosures; housing crisis; Centralized Service of Process and Attachments Offices.

\section{Resumen}

La reciente crisis económica en España puso de manifiesto la debilidad de un modelo inmobiliario que se fundamentaba en un sobreendeudamiento, fomentado y alimentado por el sistema financiero y político. La quiebra de los fundamentos de dicho sistema originó, entre otras consecuencias socioeconómicas, un incremento de los desahucios y de las ejecuciones hipotecarias, dos circunstancias que están mereciendo especial atención desde la Geografía. El artículo que nos ocupa se ha marcado dos objetivos principales: una reflexión teórica sobre el estado actual del conocimiento en materia de desposesión inmobiliaria y de desahucios, en el contexto de la crisis en España y de la dinámica global de financiarización de la economía mundial; y una interpretación metodológica a partir de nuevas fuentes de estudio, concretamente, de los procedimientos consignados por los Servicios Comunes de Notificaciones y Embargos de los Partidos Judiciales, que permiten reconocer la expresión espacial de estos fenómenos. Los resultados obtenidos enfatizan el carácter estructural que la desposesión judicializada tiene en el sistema de acumulación secundario en nuestro país y la necesidad de avanzar en el uso de los registros judiciales a partir de una correcta interpretación de las diligencias y de la depuración geográfica de la información.

Palabras clave: desahucios; ejecuciones hipotecarias; crisis inmobiliaria, Servicio Común de Notificaciones y Embargos.

\section{Introduction}

Between 1996 and 2007, 6,5 million new residences were built in Spain (Romero, Jiménez \& Villoria, 2012), while average prices grew by $135 \%$. In the meantime, the debt of households in mortgage loans rose from $66,1 \%$ to $167,9 \%$ of the GDP (OECD, 2015). This sudden growth registered in housing, urban space and mortgage loans came about as a consequence of property, business and tourist industry speculation; all these aspects of the phenomenon have been addressed 
in a number of studies (Burriel, 2008, 2011, 2014; Campos Echevarría, 2008; Etxezarreta, Hoekstra, Kol \& Cano Fuentes, 2012; Gaja i Díaz, 2008).

The subsequent burst of the real estate bubble meant that one part of the 319 billion euros in mortgage loans that had been granted in Spain could not be paid back, thereby triggering an unprecedented -for the country- wave of business bankruptcies and evictions. Foreclosures, accounting for less than 25000 in processing fees in all 431 judicial districts up until 2006, increased so sharply as to reach a staggering 214456 in 2013, according to statistics provided by the General Council of the Judiciary. Far from being exclusive to Spain, this same process has been observed in several other European countries. However, the level of buyer indebtedness and the rise in prices in our country were both so high that the consequences brought about by the bursting of the real estate bubble were considerably more serious than elsewhere (López \& Rodríguez, 2011).

Realizing the extent of the impact caused by real estate dispossession and eviction after the burst of the real estate bubble, many researchers have analyzed the phenomenon from an economic, legal, social and geographical point of view. Geographical approaches have not cast aside theoretical interpretation but have set as their priority the knowledge of global quantification and the territorial study on different scales. To this end, the first studies made use of foreclosure data, provided by the General Council of the Judiciary, from the 431 judicial districts existing in Spain (García-Hernández; Díaz-Rodríguez \& García-Herrera, 2018; Méndez, 2017; Méndez, Abad \& Echaves, 2015; Méndez, Abad \& Plaza, 2014; Méndez \& Plaza, 2016; Obeso Muñiz, 2014). These data make it possible to observe the process in the whole of Spain but on a judicial district scale, meaning that they do not distinguish houses from other types of real estate assets and do not allow researchers to either analyze evictions or to conduct urban studies. Let us not forget that, aside from the Judicial Reports and the Statistics of the General Council of the Judiciary, another secondary source of great interest is the one offered since 2014 by the National Statistics Institute on foreclosures filed in Land Registries. This information is classified by autonomous community and by trimester.

Complementary to this, other studies have been carried out based on the disaggregated analysis of judicial records of foreclosures and evictions from specific judicial districts. This is the case of the studies conducted on the judicial districts of Palma (Vives-Miró, González-Pérez \& Rullan, 2015; Vives-Miró \& Rullan, 2017), Maó in Menorca (Vives-Miró, Rullan \& González-Pérez, 2017) and Las Palmas de Gran Canaria (Parreño-Castellano et al., 2018). The advantage of such a micro-scale approach is that it makes urban geographical analysis easier, given that the address is provided for each of the properties affected by dispossession or eviction and a larger number of variables can be obtained for analysis. On the other hand, it also comes with the disadvantage of leaving out the cases that have not been subjected to a judicial procedure. 
A third line of research draws on the systematic examination of housing advertisements of real estate agencies that are linked to banks. It is estimated that around $30 \%$ of these properties derive from dispossession processes (not necessarily judicial ones), and this has given way to a series of studies on the cities of Lleida (Gutiérrez \& Domènech, 2017a), Tarragona, Terrassa and Salt (Gutiérrez \& Delclòs, 2016, 2017; Gutiérrez \& Arauzo-Carod, 2018), Alicante, Murcia and Zaragoza (Gutiérrez \& Domènech, 2017b); Madrid (Jiménez Barrado \& Sánchez Martín, 2016) as well as the total of housing properties owned by SAREB in all Spanish municipalities (Gutiérrez \& Domènech, 2017c). Having been based on geographical studies, some insights offered from other fields are also worth mentioning, as is the case of Raya (2017), whose research focuses on the autonomous communities of Madrid and Valencia. The drawback of these papers is that they do not allow the reader to identify the year of each foreclosure; they do, however, provide information on the characteristics of the property and on the bank that owns it.

Finally, the studies of Gutiérrez \& Vives-Miró (2018) and Vives-Miró \& Gutiérrez (2017) make use of the registry of empty houses in the hands of financial entities created by the Catalonian Generalitat in 2016, its aim being the creation of a special tax to be applied on these assets. This source makes it possible to find out the total number of houses accumulated by banks through foreclosure in Catalonia, providing information on the census section of each property and the entity that owns it.

In this context, two goals have been set for this paper. The first one is to offer a theoretical reflection on the issue of real estate dispossession, viewing it as an outcome of the production system at a stage of late capitalism, whose main features are the secondary accumulation system and financialization; within this late capitalism, economic and political agents use real estate dispossession (often through judicial procedures) as yet another accumulation mechanism.

The second goal is to analyze the advantages and disadvantages that the judicial records of foreclosures and evictions present as a source for the micro-scale study of the geography of real estate dispossessions and evictions. Taking into account the disparity between Centralized Service Offices and the peculiarities of this registry, we believe it is necessary to offer a theoretical reflection on its potential for analysis now that empirical research studies are beginning to proliferate, in order to avoid possible simplifications in its interpretation and to stress the advantages of comparative case studies.

To this end, and given the theoretical nature of this paper, the methodology has been based on the study of specialized texts and on our own experience of collecting information straight from the Centralized Service of Process and Attachments Offices.

The paper has the following structure: After the introduction, sections one and two contain a theoretical reflection on the relation between the production system at a stage of late capitalism and the real estate dispossession and evictions. The next section focuses on the theoretical study of 
judicial records, with a general presentation of the Centralized Service Offices and their digital records as well as an analysis of the difficulties encountered when attempting to turn a judicial record into a geographical study unit. Furthermore, the peculiarities of the different kinds of proceedings and procedures are presented here, along with the complexity entailed by their geographical dimension. The paper is completed with a list of general conclusions that outline its main contributions.

\section{System of accumulation, financialization and real estate dispossession}

In this paper what we mean by real estate dispossession is the undesired loss of possession of real estate assets (preferably houses but also business premises and other properties) through judicial procedures that may affect private individuals or companies, even though in its wider meaning the term dispossession also includes nonjudicial mechanisms.

Evictions, on the other hand, must be interpreted as the undesired loss of the use of a real estate asset as a result of a judicial procedure that may be initiated for a number of different reasons, the most common one being the nonpayment of rent. Generally speaking, dispossession is the result of a judicial enforcement (not necessarily that of a mortgage), whereas evictions are carried out through a specific judicial procedure, that of the oral hearing.

Having clarified that, the rise in foreclosures and evictions registered in Spain at the turn of the century should be interpreted as an inbred phenomenon of the production system. The capitalist system and especially late capitalism, according to Mandel's (1975) definition of it, entails a system of accumulation and reinvestment of surplus funds generated in three economic circuits: primary, aimed at the production of non-durable goods and services; secondary, related with the production of durable goods and fixed capital; tertiary, involving investment in science, technology and social services to promote the reproduction of workforce (Harvey, 2008). Lack of profitability in any of the three sectors triggers an over-accumulation crisis (Lois, Piñeira \& Vives, 2016), which in turn drives the investment of surplus towards the other sectors or forces the adoption of temporary solutions aimed at delaying it.

The channeling of capital surplus towards the secondary sector and, more specifically, towards housing construction, requires an appropriate credit system and the adoption of enabling policies by the public institutions (Gotham, 2009). Credit expansion leads to the financialization of production activities, meaning that both income and production are chiefly based on financial means, this being still another economic strategy aimed at growth. In other words, rather than facilitating business, the financial activity takes up the task of promoting its own growth (Engelen, 2003). This last aspect is precisely what leads Arrighi (1999) to refer to the past four decades as the financial phase of the 
Systemic Cycle of Accumulation and Boyer (2011) to speak of an accumulation system governed by finance.

Keeping in mind that the political line followed by Franco's administration meant to create a society of owners, which has been interpreted as a means of social control, (Naredo, 2010), since the mideighties Spanish politics has favored the secondary sector of accumulation and the financialization of the economy as its main growth mechanisms, taking advantage of the benefits offered by the country's recent admission to the European Community. To begin with, the liberalization of the rent market (1985) and the tax policies related to housing -tax exemptions, subsidies for buyers- led the capital, both national and European, to search for still more surplus in the Spanish real-estate market. This was followed by the liberalization of mortgages, which made it possible to securitize this kind of loans in secondary markets starting in 1992; the liberalization of the land market (1998), which enabled municipalities to include large pieces of land in their city planning schemes; credit expansion; and immigration policies, which allowed more than seven million people to come and settle in the country between 1994 and 2008. All these circumstances gave rise to a financialized economic system, in which real estate speculation came to be the main means of surplus generation for economic agents (López \& Rodríguez, 2010) as well as the main means of saving for the general population, thanks to the then upward trend of prices.

One condition that was necessary for this model to bring economic growth was the rise in effective demand; this was achieved, for starters, by increasing the solvency of potential buyers, so that they would be able to purchase their first house or to improve their housing conditions (Dymski, 2009); secondly, through a population increase, which explains why the arrival of immigrants was so essential. Financial credit was adapted so that larger and larger numbers of people who were previously excluded from the housing market could now acquire some real estate, despite the constantly rising prices.

That said, the accumulation of surplus in the secondary circuit, which was based on the cooperation of the real estate/construction sector, the financing system and the political-administrative system, turned into over-accumulation when in 2008 financing started to shrink, as the return prospects seemed poorer with the financing and real estate system suddenly becoming more and more unstable. The fact that the whole system relied on local bank loans supported by global funds and securitized in secondary markets goes a long way in explaining the burst of the real estate bubble (Aalbers, 2009; Fernández \& Aalbers, 2016; Martin, 2011; Newman, 2009); at the same time, the drop in demand as a result of the speculative rise in prices should be also taken in account. All this made it harder for property developers to sell and to achieve financing, often causing them serious liquidity problems in their financial commitments, and provoked the consequent shrinking of the sector, that affected the economy in its entirety. 
Consequently, the economic crisis and the rising unemployment led to a dramatic growth of default payments as more and more buyers failed to keep up with their mortgage loans. To make matters worse, these people could not even use the mortgaged property as an asset which could help them out of their debt, as market prices logically dropped, and they were therefore much lower than the amount set for the mortgage. This brought about an ever-increasing number of attachments and foreclosures, even though in many cases the assets could not help the banks improve their balance sheets, given that they could only be sold at a very low price. At the same time, as a large portion of the population was doing worse and worse financially, rent payments also failed to be met, this leading to evictions due to non-payment, which is basically another side of the same process (VivesMiró, González-Pérez \& Rullan, 2015).

In other words, the virtuous circle of the finance and real estate economy at the stage of economic expansion suddenly turned into a vicious circle of dissaving, loss of value and lowering of income and capital (Romero, 2010); all this made worse by the fact that no institutional system was put into place in order to mitigate its devastating social effects (Moore, Rodríguez \& Saca, 2013). This could have been achieved through income transfer or more flexible payment conditions (Cano \& Ełxezarreta, 2014).

In 2010, the year that saw the beginning of a political response to the new circumstances, the first measures were exclusively aimed at the restructuring of banks through mergers of savings banks, which were in certain cases turned into private banks through the Fund for Orderly Bank Restructuring -FOBR-. Two years later the same political line was followed with the nationalization of Bankia and Catalunya Bank thanks to the credit granted by the European Union and with the creation of SAREB, a company for the management of assets deriving from the bank restructuring, whose aim was to absorb the toxic assets of the new bank entities. According to Gutiérrez \& Vives-Miró (2018), in Catolonia public banks possess two thirds of the housing stock that is currently in the hands of financial entities as a result of foreclosure.

That is to say, through public debt the loss of financial entities was passed on to a public bank or "bad bank" -SAREB- with an eye to guaranteeing bank solvency by means of a financial rescue of its toxic assets, without adopting any measures in order to tackle the problem of the people affected. Coherently, the problem of the unfair minimum interest clauses of mortgages remained until a European sentence was issued in 2017, forcing bank entities to return the money unduly charged on account of these clauses. Banks refused to accept dation in payment, that is, the formula through which customers give up the mortgaged property in return for a cancellation of their debt -a demand of the aforementioned platforms supporting the people affected-, and the everyday drama that a large part of the population was undergoing was completely ignored. The government's only concern at that point was to eliminate the toxic assets from the financial system, while zero attention was paid to the growing social unrest. 
In 2013 these assets started to be sold and for the purpose of attracting foreign investors a new policy was adopted, which allowed for tax benefits and abolished bureaucratic barriers. Investment funds -vulture funds- purchased one part of the assets of SAREB and of other financial entities at prices that were more than advantageous, through instruments like Real Estate Management Companies, Servicers and SOCIMIS (Abellán, 2015), at a time when there seemed to be good prospects of profitability. This internationalization of housing property is the last step towards its financialization as well as the key element to understanding how a model of accumulation gave way to one of accumulation through real estate dispossession (Harvey, 2003) and later recovery of possession. In fact, Spain is considered to be one of the European countries with the highest rates of property recovery (Janoschka, 2015).

In the given context, real estate dispossession and loss of the right to use a dwelling, and their subsequent recovery would not have come about, had it not been for the design and adoption of a deliberate policy which could guarantee benefits for large investors from abroad, for major economic agents and for financial entities. Some made huge profits from the real estate dispossession of others, others cleaned up their balance sheets through the impoverishment of the population. This connotation of Spanish politics has led certain authors to define this new mechanism of accumulation in the case of Spain as real estate dispossession by political fraud (Alexandri \& Janoschka, 2018).

\section{Urban vulnerability and citizen response}

Needless to say, the economic model outlined over the previous paragraphs dramatically aggravated social vulnerability for a large number of buyers. The term vulnerability is here understood as limited capacity to respond to unfavorable circumstances (Moser, 1998), and therefore as fragility in the face of adversity, something that became apparent when many of these individuals saw their income shrink substantially. It should also be borne in mind that the crisis, starting in 2007 only to be exacerbated by the neoliberal austerity policies imposed by the European Union from 2010 onwards, has severely deteriorated life conditions for a large part of the population. This is because such policies were mainly based on the deregularization of the labor market and the privatization of public services -most importantly, education and healthcare-.

The direct consequence was an increase in social inequality, especially with regard to the labor market, as millions of jobs vanished or became much more precarious, this affecting professional groups and territories that previously seemed to be immune; parallel to this, the salary devaluation has further polarized the labor pyramid and widened the gap between its two ends (Méndez, 2017, p. 18). 
The crisis has therefore given rise to a model of social cohesion that is characterized by exclusion, based as it is on the intensification and generalization of social differences and on an increasingly unstable labor market. This leads to less public support in the individual's process of social integration and thus to an even deeper social fracture (Manzanera-Román, Ortiz \& Hernández, 2016). These circumstances are made particularly evident in the case of non-EU foreign immigrants, who present an even higher level of social vulnerability from the very beginning, regarding both their legal condition and their reduced social capital. North American studies have frequently pointed out the relation between immigration, race and debt (Fields, 2015; Walks, 2013); bearing in mind the connotations of the Spanish migration model, this relation can be largely extrapolated to our geography of real estate dispossession.

Increased social vulnerability among certain groups, given the rise in unemployment, the closing down of companies, the loss of real estate value, evictions and real estate dispossession, has led to increased urban vulnerability in large parts of the cities, especially those traditionally inhabited by the most deeply affected social groups. This is the case of the districts that housed the majority of immigrants who arrived in Spain right in the heat of its economic boom. Judged by their borrowers as having more unstable financial means, these immigrants "were charged substantially higher interest rates in their mortgages than their native counterparts" (Díaz-Serrano \& Raya, 2014, p. 22), which meant that when the real estate bubble burst and employment took a plunge, they could no longer satisfy their loan payments, consequently losing possession of the properties they had purchased.

In addition to this, certain cities have been hit worse than others, as a result of the unequal impact that the economic crisis has had on different areas (Méndez, 2013). Dispossession is therefore a mechanism that promotes inequality in and between cities, following the logic of capitalist development, which by definition favors spatial inequality (Brenner, 2009).

From this last perspective, cities as spaces are highly illustrative of the impact caused by the crisis. If, on the one hand, they concentrate population, activities, companies, institutions, know-how and innovations that serve to boost the economy in times of growth, they are also the parts of the territory that are most deeply affected when there is a recession (Caravaca, González-Romero \& López, 2017, p. 3).

That said, it is necessary to go back to the time period that preceded the economic crisis in order to fully understand the current housing problem in cities. The predominating family-centered model also known as "the familist model" - in Spain has given rise to what some researchers call "patrimonial welfare state", in which families tend to accumulate assets, and especially owned dwellings (Leal, 2015). Under these circumstances, the expectations of many new owners were suddenly dashed by the crisis and all its effects. Unable to keep paying their mortgages, many were 
evicted from their dwellings, and on top of that, most of the times it was impossible for them to afford any rent available on the market, as the stock of social housing was gradually diminishing, sometimes even becoming non-existent. This situation soon sparked a strong social reaction.

In 2009 Barcelona saw the birth of an association and a social movement known as the Platform for People Affected by Mortgages -Plataforma de Afectados por la Hipoteca or PAH- (Colau \& Alemany, 2012; Mangot, 2013). This movement gradually spread throughout the country and was further boosted by the 15M movement and district assemblies. More precisely, one of the first groups to get organized in order to react to the mortgage fraud that had affected them was the National Coordinating Body of Ecuadorians in Spain. This and other similar organizations started taking different kinds of action, such as pressing financial entities to address the issue of people who had been evicted or who were in danger of getting evicted, forcing the administration to come up with a solution to the problem, offering legal advice to the people affected and actively trying to paralyze evictions -Stop Evictions campaign- (Camacho et al., 2015).

Despite the effectiveness of these movements, a substantial rise in foreclosures and evictions was registered from 2008 onwards. This led the people affected or those at risk to adopt different strategies of resilience, such as returning to their parents' home or receiving financial help from their closest relatives so they could pay rent or their debts with the bank, these being typical modes of transgenerational resource transfer in times of crisis (Marí-Klose \& Martínez, 2015). Another adaptation strategy has been that of using "tricks" against evictions, in the form of successive nonpayments, illegal squatting, in certain cases the result of the pressing need to find a roof under which to live, and in others because of a conscious decision to adopt an alternative lifestyle with regard to residence and cohabitation; in short, an array of situations corresponding to the wide variety of legal procedures in place (Sala, 2018).

Finally, for a better understanding of the following sections, it should be pointed out that this judicialization of the loss of housing is to be considered as just one of the many parts of the real estate dispossession process, even though it is probably the most dramatic one. It could in fact be seen as the tip of the iceberg, given that many other mechanisms have been activated with the intention of alleviating or altogether solving specific economic problems, which end up further undermining the right to a home. "Forced" sales, dation in payment, out-of-court settlements with banks or third parties are only some of them. Besides, it should not be forgotten that, before a foreclosure takes place, in many cases the people affected have already had other assets, properties and incomes of theirs attached. The global figures about foreclosures do not therefore do justice to the actual problem caused by the development model that has been promoted over the past decades, even though estimates say that since the beginning of the crisis there have been no fewer than 400,000 foreclosures in Spain (Méndez, Abad \& Plaza, 2014). 


\section{The Centralized Service of Process and Attachments Office as a source of analysis}

The primary source of judicial data for the study of evictions and foreclosures is made up by the different writs issued by the Courts of First Instance, which keep a record of their operations, even though their inventory might not be in the most adequate conditions research-wise.

Besides that, Spanish Judicial Parties with a considerable demographic size are equipped with a Centralized Service of Process and Attachments Office, a procedural law unit set up through organic Law 19/2003 of December 23, which modified the organizational structure of the Judicial Power; this unit was later further developed through Regulation 2/2010. The aforementioned Law had already defined the Centralized Service Offices, establishing their set-up and functions, while leaving their design, creation and organization to the Ministry of Justice and the autonomous communities. The Regulation, on the other hand, in its Title II, enumerates the criteria for the standardization of their operations and specifies that Centralized Service Offices with the function of issuing proceedings for notices and executions are authorized to take as many actions as they deem necessary in order to effectively carry out the content of those proceedings entrusted to them by the Courts, such as ejectments, foreclosures, etc. With such functions of registry and distribution entrusted to them, the Offices need to be equipped with a computer application that enables them to digitally process documents. In charge of this Service is a Legal Counsellor from the Justice Administration -former Senior Clerk of the Court- who acts as its Director and is assisted by a team of civil servants from the Services of Court Operations Officers, Court Administration Officers and Social Assistance Officers.

The inventory structure is not the same in all of the autonomous communities but, despite the differences brought about by the decentralization of such decisions, it still enables us to adopt a similar approach to the study of eviction and real estate dispossession.

The information contained in these records is normally published by the High Courts of Justice of the different autonomous communities in their annual Judicial Reports. Also, a summary of this information, collected from the whole country, is published by the General Council of the Judiciary through its Service of Judicial Statistics. The original information, in its full extension, is only available to the members of the courts or the Centralized Service Offices.

The fields contained in the record of every proceeding may vary from one autonomous community to another, but usually include: number of proceeding, legal representative, type of proceeding, issuing court, address, procedure, entry date, operation date and state. The information provided is therefore limited but still valuable and ultimately allowing access to the files. 
The fact that we can be informed of the volume of operations and the types of procedures within a specific time frame and a demarcated territory makes this source of data a valuable instrument for the space and time analysis of urban vulnerability.

\subsection{The information unit for the study of evictions and foreclosures}

In this section we are going to focus on two aspects that need to be taken into account if a more accurate interpretation is to be made of the records provided by the Centralized Service of Process and Attachments Office as a resource for the study of eviction and real estate dispossession: on the one hand, the difficulty of defining a valid unit of information for the given purpose and, on the other, the way in which this unit can be extrapolated to the concepts of real estate dispossession and eviction.

The first thing to take into consideration when defining an operative unit of information is that we are dealing with a judicial registry, meaning that each entry corresponds to a judicial act or record and therefore, strictly speaking, we cannot associate a record with a person, or even with a property. Most of the times, some link does exist between a record and a property but it is much more uncommon to find such a relation between record and person. Behind an eviction record, for instance, there may be a one-person household but also multiple households, as such information on a property's residents is not usually provided.

By contrast, it may happen that one single property appears in more than one record, due to the way in which the judicial procedures have been conducted or because that property has undergone more than one procedure over the years. Given that the unit of geographical analysis that most closely resembles the data found in judicial records is the property, a meticulous filtering of the information is needed in order to eliminate cases such as the ones mentioned above, if a proper geographical interpretation of the problem is to be achieved. Otherwise, we could still obtain a useful general overview of eviction and real estate dispossession but our information would not be accurate enough for a microscale analysis.

A study of the legal representative involved may allow us to delve further into each case and therefore filter the information in an appropriate way. At times, two identical records may appear, the only difference between them being the different legal representatives. More precisely, in some cases the number assigned to the record and the legal representative changes, while the record itself, courthouse, address, process, entry date, date of the operation and state are exactly the same. This happens, for example, when the procedure is carried out on a property of a person and of a company whose owner is that same person, or when the property in the record belongs to a man and a woman who are married in community of property, if this has been thus stated in a proceeding submitted by a Court of Law. Consequently, one record does not always correspond to one property and therefore identical records need to be eliminated, given that our interest does not 
lie in the number of people -which is impossible to know when using this source of data since behind the one person mentioned there may be a whole family- but rather in the number of properties affected.

Another aspect to bear in mind regarding the unit of analysis is that records may refer to dwellings, business premises or other kinds of real estate properties -storage rooms, garages, plots of land-. It is not an easy task to classify records according to the kind of property affected; a detailed examination is needed, especially in order to distinguish dwellings from business premises, as it is not uncommon to find properties initially conceived as dwellings, which have been converted into business spaces and are currently used as such. On the other hand, from a conceptual point of view, loss of possession through the execution of judicial proceedings does not always affect dwellings. It may well be related to a real estate asset of lesser value, such as a garage or a shed, or one of higher value, such as a plot of land.

\subsection{The judicial proceeding and procedures}

The other issue that is of great importance for the interpretation of this source is the way in which the concepts of eviction and real estate dispossession may be extrapolated to judicial proceeding terminology (diligencias). Among the records we find three types of proceedings: attachment (embargo), ejectment (lanzamiento) and transfer of possession (toma de posesión). Attachment, contrary to what one may think, cannot be translated through the terms we have mentioned. It is true that debts, including mortgages, may cause the issuing of writs of attachment, but this only translates into dispossession of a real estate asset when an act of foreclosure or the execution of a court proceeding have been completed. This usually takes a long time, depending on the total amount of the debt and on the type of claimant. On the other hand, mortgages or other kinds of debts may lead to attachment of incomes or movable assets. Attachment figures are therefore a good indicator of the population's socioeconomic conditions and as such can help assess different situations brought about by the crisis and their social repercussions, but cannot offer a direct interpretation of real estate dispossession processes. Besides, the General Council of the Judiciary itself warns that the data on attachments are not very reliable in the case of the Centralized Service Offices because many courts of law execute them in a direct manner, without asking the Offices to intervene. Consequently, attachment notices need to be excluded from the database, if this is to be used for urban studies.

An adequate reading of real estate dispossession makes it necessary to consider not just ejectment but also transfer of possession. The former means that there is a person, either physical or legal, being ejected -expelled-, while the latter applies to an asset whose ownership changes without an ejectment necessarily taking place. This may happen, for example, when the person who is being ejected has already abandoned the property or when the transfer of possession concerns an asset 
which is not currently used. In this respect, it must be borne in mind that the concept of ejectment, as it appears in the statistics of the General Council of the Judiciary, seems to encompass both types of proceedings ${ }^{1}$.

On the other hand, among the proceedings of ejectment and transfer of possession only those presenting a positive state -denoting completion of the process -should be considered. It is therefore rather risky to include those in which a different state is marked as the criteria for the description of the state may vary between Offices or even within the same Office depending on the year. The zeal with which actions related with a procedure are registered may at times lead to reality being blown out of proportion in some judicial districts, at least according to our observation of certain years. This means that global time series based on the records may not be altogether reliable and that comparisons between territories in summary statistics may lead to errors of assessment. Furthermore, for a number of reasons sometimes procedures do not end up in an actual eviction or real estate dispossession.

Loss of housing cannot simply be interpreted as the result of not being able to pay for rent or for a mortgage loan; it should rather be looked at in the context of a more general economic crash, both in terms of business and as an outcome of a consumption-driven economic model coming to an end. Nor should it be overlooked that loss of housing may also be related to families breaking up or to conflicts over inheritance issues - processes that tend to multiply when there is an economic crisis- or even to sentences imposed for criminal offences. For all these reasons, it is necessary to start from the study of proceedings and then move on to that of procedures when examining each case.

In the field of procedure (procedimiento), the information needs to be meticulously rearranged given the wide variety of situations it covers, in line with the diversity of reasons for which possession or use of a property may be lost. The situations found may be connected to civil, criminal, arbitration, bankruptcy or family law procedures, among others, as can be observed in table 1, which also includes the procedures that are occasionally linked to requests by other courts - national assistance and rogatory letter - and to other situations such as the separate section of precautionary measures or collection proceedings. A variety of different legal procedures that may lead to loss of the use of a property are also to be found in the records (see Table 1).

1 In its clarification of concepts, the General Council of the Judiciary states the following: "One ejectment is recorded for each real estate asset for which ejectment or turnover of possession has been decided, regardless of the number of notifications it may have generated or the type of procedure initiated or the phase in which the latter is, as long as the said ejectment entails a change of possession of the asset, be it a rustic property or an urban one, a dwelling or not. For statistical purposes, the ejectment section will include both ejectments in the execution phase and turnovers of possession, as well as resolutions that bring about mediate possession through voluntary turnover of the asset, either to the interested party or to the judicial organ". 
Even though our experience tells us that many of these procedures are scarcely found, it is still true that eviction and real estate dispossession situations are not only due to non-payment of the rent or the mortgage loan. Recovery of rented property by the owner, debt accumulation, personal or company bankruptcy, family breakup, criminal offences, conflicts over inheritance, etc. may also help explain the figures. This means that we cannot automatically establish a simple and direct relation between mortgage and loss of possession, but rather a more complex relation with the financialization and breakdown of the economic model. Similarly, the exercise of one's rights on property may bring about another set of eviction cases. It is therefore necessary to bear in mind the multiplicity of personal situations when approaching this phenomenon, despite the fact that most actions taken by Centralized Service Offices and Courts of First Instance are enforcement of a court order and foreclosure -loss of property-, and oral hearings for non-payment and eviction -loss of use- .

Table 1. Classification of procedures

\begin{tabular}{|l|l|}
\hline \multicolumn{2}{|c|}{ PROCEDURES LEADING TO THE LOSS OF PROPERTY } \\
\hline Civil procedures & $\begin{array}{l}\text { - Enforcement of court order } \\
\text { - Foreclosure }\end{array}$ \\
& $\begin{array}{l}\text { - Enforcement of out-of-court order } \\
\text { - Provisional enforcement }\end{array}$ \\
\hline - Individual enforcement
\end{tabular}

Source: own elaboration 
Another relevant aspect is the date of the operation. The time that elapses between the beginning of a procedure and its completion is variable and depends on the situations that may come about during its execution. Although the procedure of an eviction for non-payment of the rent usually takes less than a year and a half and that of a foreclosure less than two years, there are many cases in which more time is required. The date when the operation completing the procedure effectively takes place is therefore a useful piece information if we are to approach the evolution of the problem, albeit in a superficial or nuanced way.

\subsection{The address in the records and the spatial analysis of real estate dispossession}

The norm requires that the address on the debtor's mortgage deed for notices and requests be that of the dwelling or business premises corresponding to the property being mortgaged (art. $682.2^{\circ}$ LEC), which is also the one recorded by the Registrar on the registration of mortgage deed (art. 682.3 LEC) Nevertheless, there are certain exceptions that need to be taken into account if real estate dispossession is to be accurately portrayed in terms of intraurban geography. First of all, the address given is occasionally that of the creditor or its intermediate agents, a practice imposed by credit banks. Consequently, a detailed analysis is needed so that addresses of notary's offices and banks can be eliminated. Secondly, in certain cases, the address does not correspond to the property affected by the procedure but to the place where the notice has been sent. This means that post office boxes, hotel addresses and even prisons may appear, which have to be eliminated, along with addresses belonging to territories outside the jurisdiction examined, as the persons involved in these cases do not reside in the area studied. Such records of the number of procedures and actions do not only fail to offer geographical information but they can even corrupt the cartographical expression of the results due to mistakes in the location of certain procedures.

Although the cartographical database needs this kind of refining, it should be stressed that the greatest advantage offered by the field of address in the records is that it makes it possible to work on different geographical scales, through the process of data aggregation according to the criteria adopted in each territorial analysis: plots of land, streets, census tracts, neighborhoods, districts, etc. Nevertheless, difficulties also crop up when the data is analyzed with the aim of a future georeferentiation. Given that the smallest unit has to be the cadastral plot, the addresses given must be examined in detail to make sure they correspond to the name found in the municipal street plan and to its numeric code, while they must also be properly processed in order to be adapted to a polygon topology. For the first purpose, some field work will be necessary whereas, for the second, a process should be established allowing us to assign more than one record to the same plot of land, for those cases in which two or more dwellings or offices located in the same building are affected. 
In any case, the results obtained offer an extraordinarily wealthy cartographic expression that allows us to link the database to the information provided by the Electronic Service of the General Directorate for the Cadastre, or the information found in other territorial units, such as Census Tracts or Districts of the National Statistics Institute. Consequently, in the microscale analysis explained here the units of observation will be the micro-spaces demarcated and adopted as the smallest pieces on the basis of which territorial behavior can be determined (Ocaña, 2005; Parreño \& Domínguez, 2008).

\section{Conclusions}

Over the previous sections we have developed our theoretical reflection on real estate dispossession and evictions in Spain. We have first delved into the conceptual dimension of both these terms and into the reasons why over the past few years we have been witnessing a rise in these two processes. Secondly, we have analyzed the main features of one of the most interesting sources for geographical study, that of the judicial records of the Centralized Service of Process and Attachments Offices.

The reasons behind the processes of real estate dispossession and loss of use can be approached from a particular and a general perspective. In the first case, dispossession and loss of use tend to be conceived as a consequence of the inability of the people affected to meet their loan or rent payments. Though this may be true, in this paper we have wished to make two clarifications that need to be taken into account in geographical analyses. On the one hand, the procedures enable us to observe how real estate dispossession, and to a lesser extent the loss of use, is due to a series of fairly different reasons, ranging from family and inheritance disputes to criminal and civil offenses. On the other hand, in the case of real estate dispossession, we must keep in mind that demands for repayment of non-mortgage-related debt generate a large number of judicial enforcements, although financial entities still being the ones that benefit from these procedures.

As has been pointed out in this paper, from a general perspective, real estate dispossession and evictions must be interpreted as a consequence of the production model that was established in Spain in the 1980's, the same being true of many other countries, without underestimating the relevance of other factors that go even further back in history. It is true that the economic crisis raised significantly the number of judicial procedures, but this would not have happened, had it not been for the economic and political bases that were set in the preceding decades.

The choice of a model of secondary accumulation as the driving force of production, the financialization of production activities, the flexibilization of financing conditions, the liberalization of the land market, tax policies that favored the purchase of real estate, etc. all form part of these bases. Besides that, we consider that the extent of the real estate dispossession and eviction issue 
can be explained by the fact that the economic and political agents have, in perfect unison, adopted measures to save the accumulation system, applying the logic of financial power. It is in this sense that we should interpret the neoliberal measures adopted, which brought on the sociabilization of the financial debt and the involvement of international agents capable of accumulating benefits on the basis of real estate dispossession and deprivation of use.

From our point of view, this is chiefly a structural problem linked to the production system that has gone through a number of phases, among which at least one of accumulation by real estate possession and another by real estate dispossession and deprivation of use. For all this to work, quick judicial action in the dispossession and deprivation of use processes is necessary, and this can be achieved through mortgage regulation and the so-called express evictions; this is why it is so important to move forward in the geographical analysis of judicial sources.

For this reason, the second aim of this theoretical reflection focuses on the analysis of judicial procedure records. Information drawn from the records of the Centralized Service of Process and Attachments Offices has a great potential for the microscale study of the processes of real estate dispossession and loss of use, thus revealing itself as a powerful tool for the identification of urban vulnerability. The analysis presented here means to point out certain aspects that need to be taken into account if a refined urban interpretation of real estate dispossession and evictions is to be achieved.

The first one is the difficulty they pose in defining a valid unit of information since, although there is generally a correlation between registered procedure and asset, this is not always the case, as sometimes duplicates of the same record are found. Considering this, we feel that, since the asset itself is the unit of geographical analysis that best represents the data registered, it is essential to thoroughly filter the information in order to offer a geographical reading with an adequate scope and to refine the database in a way that the best possible results are guaranteed.

Another aspect to take into consideration is how the concepts of eviction and real estate dispossession can be extrapolated to the terminology of judicial proceedings: attachment, ejectment and transfer of possession. Attachments, given their procedural characteristics, may serve as an indicator of the population's socioeconomic conditions and are therefore useful for an assessment of the crisis and its social repercussions, but have no direct bearing on real estate dispossession processes. Ejectments and positive transfers of possession are proceedings that do allow for knowledge of the real estate dispossession and evictions, their only difference being that the former involves a physical or legal person being expelled, while the latter describes the process through which somebody officially gains possession of the asset, without this necessarily implying an ejectment. Nevertheless, in some of the studies conducted in recent years only ejectments are taken into consideration, something that results in less representative samples. 
Thirdly, it is necessary for urban studies to descend to the field of procedure. There is a large number of situations leading to loss of property or of its use, and this diversity of situations is reflected in the variety of procedures. Their treatment offers a more accurate vision of the subject under study, but it definitely requires a greater degree of correspondence between geographical analysis and analysis conducted in other disciplines.

Finally, even though the address is certainly the most valuable element available to us when using this source of information as a tool for spatial representation and for work on different geographical scales, it should be borne in mind that spatial treatment is not free of problems. The judicial procedure establishes that the address on the debtor's deed should be, for the purpose of notices and requests, that of the dwelling or business office affected. However, in actuality we do find other addresses where notices are sent. This makes it necessary to determine which of the addresses present in the records actually corresponds to the procedures described in order to obtain an accurate image of the intraurban real estate dispossession geography. Mechanisms must be put into place which ensure that geographical information is more accurate; this could be occasionally achieved through direct contact with judicial agents and specific attention paid to duplicates.

R\&D project "Crisis and vulnerability in Spanish island cities: transformations in social reproduction spaces", funded by the State Research Agency (AEI) and the European Regional Development Fund (ERDF).

Acknowledgments: We would like to express our gratitude to Common Service of Notifications and Liens of the Judicial District for Las Palmas de Gran Canaria and to its head, for the support given. This research was funded by the State Research Agency (AEI) and the European Regional Development Fund (ERDF) with R\&D project "Crisis and vulnerability in Spanish island cities: transformations in social reproduction spaces" (CSO2015-68738-P).

Authorship statement: The authors declare no conflict of interest. Conceptualization: Juan M. Parreño Castellano \& Josefina Domínguez Mujica. Consulting and treatment of original sources: Juan M. Parreño Castellano, Matilde Teresa Armengol Martín, Josefina Domínguez Mujica, Tanausú Pérez García \& Jordi Boldú Hernández. Research and writing: Juan M. Parreño Castellano \& Josefina Domínguez Mujica. 


\section{References}

Aalbers, M. (2009). The globalisation and Europeanisation of mortgage markets. International Journal of Urban and Regional Research, 33, 389-410. https://doi.org/10.1111/j.1468$\underline{2427.2009 .00877 . x}$

Abellán, J. (2015). La vivienda, los fondos de inversión y la reestructuración del capitalismo español. Retrieved from http://contested-cities.net/CCmadrid/la-vivienda-losfondos-de-inversion-yla-reestructuracion-del-capitalismo-espanol

Alexandri, G., \& Janoschka, M. (2018). Who loses and who wins in a housing crisis? Lessons from Spain and Greece for a nuanced understanding of dispossession. Housing Policy Debate, 28(1), 117-134. https://doi.org/10.1080/10511482.2017.1324891

Arrighi, G. (1999). El largo siglo XX. Madrid: Akal.

Brenner, N. (2009). A thousand leaves: notes on geopraphies of uneven spatial development. In R. Keil \& R. Mahon (Eds.), Leviathan Undone? Towards a Political Economy of Scale (pp. 27-49). Vancouver: UBC Press.

Boyer, R. (2011). Is a finance-led growth regime a viable alternative to Fordism? A preliminary analysis. Economy and Society, 29, 111-145. htps://doi.org/10.1080/030851400360587

Burriel, E. L. (2008). La "década prodigiosa" del urbanismo español (1997-2006). Scripta Nova, XII, 270(64). Retrieved from http://www.ub.es/geocrit/sn/sn-270/sn-270-64.htm

Burriel, E.L. (2011). Subversion of land-use plans and the housing bubble in Spain. Urban Research \& Practice, 4(3), 232-249. https://doi.org/10.1080/17535069.2011.616743

Burriel, E.L. (2014). El estallido de la burbuja inmobiliaria y sus efectos en el territorio. In J.M. Albertos Puebla \& J.L. Sánchez Hernández (Eds.), Geografía de la crisis económica en España (pp. 101-140). Valencia: Universidad de Valencia.

Camacho, J., Díaz Orueta, F., Gadea, M. E., Giné, X., \& Lourés, M. L. (2015). Derecho a la vivienda y cambio social: la Plataforma de afectados por la hipoteca de Madrid. In J. Subirats \& A. García Bernandos (Eds.), Innovación social y políticas urbanas en España: experiencias significativas en las grandes ciudades (pp. 113-119). Barcelona: Icaria.

Campos Echevarría, J.L. (2008). La burbuja inmobiliaria española. Madrid: Marcial Pons.

Cano Fuentes, G., \& Etxezarreta Etxarri, A.J. (2014). La crisis de los desahucios en España: respuestas institucionales y ciudadanas. Revista de Economía Crítica, 17, 44-57.

Caravaca, I., González-Romero, G., \& López, P. (2017). Crisis y empleo en las ciudades españolas. Eure, 43(128), 31-54. 
Colau, A., \& Alemany, A (2012). Vidas hipotecadas. De la burbuja inmobiliaria al derecho a la vivienda. Barcelona: Cuadrilátero de libros.

Diaz-Serrano, L., \& Raya, J. M. (2014). Mortgages, immigrants and discrimination: An analysis of the interest rates in Spain. Regional Science and Urban Economics, 45, 22-32. hitps://doi.org/10.1016/j.regsciurbeco.2013.12.004

Dymski, G.A. (2009). Afterword: Mortgage markets and the urban problematic in the global transition. International Journal of Urban and Regional Research, 33(2), 427-442. hitps://doi.org/10.1111/j.1468-2427.2009.00869.x

Engelen, E. (2003). The logic of funding European pension restructuring and the dangers of financialisation. Environment and Planning A, 35, 1357-1372.

Etxezarreta Ełxarri, A., Hoekstra, J., Dol, K., \& Cano Fuentes, G. (2012). De la burbuja inmobiliaria a las ejecuciones hipotecarias. Ciudad y Territorio, 174, 597-613.

Fernández, R., \& Aalbers, M. (2016). Financialization and housing: Between globalization and Varieties of Capitalism. Competition \& Change, 20(2), 71-88.

Fields, D. (2015). Contesting the financialization of urban space: community organizations and the struggle to preserve affordable rental housing in New York City. Journal of Urban Affairs, 37(2), pp. 144-165. https://doi.org/10.1111/juaf.12098

Gaja i Díaz, F. (2008). El "tsunami urbanizador" en el litoral mediterráneo. El ciclo de hiperproducción inmobiliaria 1996-2006. Scripta Nova, XII, 270(66). Retrieved from http://www.ub.es/geocrit/sn/sn-270/sn-270-66.htm

García-Hernández, J. S., Díaz-Rodríguez, M. C., \& García-Herrera, L. M. (2018). Auge y crisis inmobiliaria en Canarias: desposesión de vivienda y resurgimiento inmobiliario. Investigaciones Geográficas, 69, 23-39. https://doi.org/10.14198/INGEO2018.69.02

Gotham, K.F. (2009). Creating liquidity out of spatial fixity: The secondary circuit of capital and the subprime mortgage crisis. International Journal of Urban and Regional Research, 33(2), 355-371. hitps://doi.org/10.1111/j.1468-2427.2009.00874.x

Gutiérrez, A., \& Arauzo-Carod, J.M. (2018). Spatial Analysis of Clustering of Foreclosures in the Poorest-Quiality Housing Urban Areas: Evidence from Catalan Cities. ISPRS International Journal of Geo-information, 7(1), 23. https://doi.org/10.3390/ijgi7010023

Gutiérrez, A., \& Delclòs, X. (2016). The uneven distribution of evictions as new evidence of urban inequality: A spatial analysis approach in two Catalan cities. Cities, 56, 101-108. htpps://doi.org/10.1016/j.cities.2016.04.007 
Gutiérrez, A., \& Declòs, X. (2017). Geografía de la crisis inmobiliaria en Cataluña: una lectura a partir de los desahucios por ejecución hipotecaria. Scripta Nova, XXI(557). Retrieved from http://revistes.ub.edu/index. php/ScriptaNova/article/view/557.

Gutiérrez, A., \& Domènech, A. (2017a). The Spanish mortgage crisis: Evidence of the concentration of foreclosures in the most deprived neighbourhoods. Die Erde, 148(1), 39-57. http://dx.doi.org/10.12854/erde-148-29

Gutiérrez, A., \& Domènech, A. (2017b). Geografía de los desahucios por ejecución hipotecaria en las ciudades españolas: evidencias a partir de las viviendas propiedad de la SAREB. Revista de Geografía Norte Grande, 67, 33-52. http://dx.doi.org/10.1344/sn2017.21.17734

Gutiérrez, A., \& Domènech, A. (2017c). Spanish mortgage crisis and accumulation of foreclosed housing by SAREB: a geographical approach. Journal of Maps, 13(1), 130-137. http://dx.doi.org/10.1080/17445647.2017.1407271

Gutiérrez, A., \& Vives-Miró, S. (2018). Acumulación de viviendas por parte de los bancos a través de los desahucios: geografía de la desposesión de vivienda en Cataluña. EURE, 44(132), 5-26. http://dx.doi.org/10.4067/s0250-71612018000200005

Harvey, D. (2003). The 'New' Imperialism: Accumulation by dispossession. Oxford: Oxford University Press.

Harvey, D. (2008). The right to the city. New Left Review, 53, 23-40. Retrieved from https://newleftreview.org/ll/53/david-harvey-the-right-to-the-city

Janoschka, M. (2015). Politics, citizenship and disobedience in the city of crisis: a critical analysis of contemporary housing struggles in Madrid. Die Erde, 146(2-3), 100-112. http://dx.doi.org/10.12854/erde-146-9

Jiménez Barrado, V., \& Sánchez Martín, J.M. (2016). Banca privada y vivienda usada en la ciudad de Madrid. Investigaciones Geográficas, 66, 43-58.

hHp://dx.doi.org/10.14198/INGEO2016.66.03

Leal Maldonado, J. (2015). De la burbuja inmobiliaria a los movimientos sociales de los desahuciados. In J. Subirats \& A. García Bernandos (Eds.), Innovación social y políticas urbanas en España: experiencias significativas en las grandes ciudades (pp. 120-144). Barcelona: Icaria.

Ley 1/2000, de 7 de enero, de Enjuiciamiento Civil. Publicada en el Boletín oficial del Estado núm. 7, de 8 de enero de 2000. Retrieved from https://www.boe.es/buscar/doc.php?id=BOE-A$\underline{2000-323}$

Ley Orgánica 19/2003, de 23 de diciembre, de modificación de la Ley Orgánica 6/1985, de 1 de julio, del Poder Judicial. Publicada en el Boletín Oficial del Estado núm. 309, de 26 de 
diciembre de 2003, páginas 46025 a 46096. Retrieved from https://www.boe.es/buscar/doc. php?id=BOE-A-2003-23644

Lois, R., Piñeira, M. J., \& Vives, S. (2016). El proceso urbanizador en España (1990-2014): una interpretación desde la geografía y la teoría de los circuitos de capital. Scripta Nova, XX(539). Retrieved from http://www.ub.edu/geocrit/sn/sn-539.pdf

López, I., \& Rodríguez, E. (2010). Fin de ciclo. Financiarización, territorio y sociedad de propietarios en la onda larga del capitalismo hispano (1959-2010). Madrid: Traficantes de Sueños.

López, I \& Rodríguez, E. (2011). The Spanish Model. New Left Review, 69, 5-28. Retrieved from https://newleftreview.org/ll/69/isidro-lopez-emmanuel-rodriguez-the-spanish-model

Mandel, E. (1975). El capitalismo tardío. México: Ediciones ERA.

Manzanera-Román, S., Ortiz García, P.. \& Hernández Pedreño, M. (2016). Crisis del factor trabajo como vía de integración social. Cuadernos de Relaciones Laborales, 34(1), 15-35.

Mangot Sala, L. (2013). La plataforma de afectados por la Hipoteca. De la Crisis a la Estafa. Del Prozac al Empoderamiento. Clivatge. Estudis i testimonis sobre el conflicte i el canvi socials, 2, 5687.

Marí-Klose P., \& Martínez, A. (2015). Empobrecimiento en tiempos de crisis: vulnerabilidad y (des) protección social en un contexto de adversidad. Panorama Social, 22, 11-26.

Martin, R. (2011). The local geographies of the financial crisis: from the housing bubble to economic recession and beyond. Journal of Economic Geography, 11(4), 587-618. http://dx.doi.org/10.1093/jeg/lbq024

Méndez, R. (2013). Crisis económica, vulnerabilidad urbana y desempleo en España. Ciudad y Territorio, 178, 649-667.

Méndez, R. (2017). De la hipoteca al desahucio: ejecuciones hipotecarias y vulnerabilidad territorial en España. Revista de Geografía Norte Grande, 67, 9-31. http://dx.doi.org/10.4067/S0718$\underline{34022017000200002}$

Méndez, R., Abad, L.D., \& Echaves, C. (2015). Atlas de la crisis. Impactos socioeconómicos y territorios vulnerables en España. Valencia: Tirant lo Blanch.

Méndez, R., Abad, L.D., \& Plaza, J. (2014). Geografía de las ejecuciones hipotecarias en España. Madrid: Fundación Primero de Mayo.

Méndez R., \& Plaza, J. (2016). Crisis inmobiliaria y desahucios hipotecarios in España: una perspectiva geográfica. Boletín de la Asociación de Geógrafos Españoles, 71, 99-127. http://dx.doi.org/10.21138/bage.2276 
Moore, M., Rodríguez, N. \& Saca, N. (2013). Mortgage markets and foreclosure processes in Europe and the United States. In C. Enoch, L. Everaert, T. Tressel \& J. Zhou (Eds.), From fragmentation to financial integration in Europe (pp. 409-432). Washington: IMF.

Moser, C.N. (1998). The asset of vulnerability framework: reassessing urban poverty reduction strategies. World Development, 26(1), 1-19.

Naredo, J.M. (2010). El modelo inmobiliario español y sus consecuencias. Boletín CF+S, 44. http://dx.doi.org/10.7760/bcf.s

Newman, K. (2009). Post-Industrial Widgets: Capital Flows and the Production of the Urban. International Journal of Urban and Regional Research, 33, 314-331. http://dx.doi.org/10.1111/j.1468-2427.2009.00863.x

Obeso Muñiz, I. (2014). Análisis geográfico de los desahucios en España. Ería, 95, 327-342. http://dx.doi.org/10.17811/er.95.2014.327-342

Ocaña Ocaña, C. (2005). Microanálisis sociodemográfico de espacios urbanos. Boletín de la Asociación de Geógrafos Españoles, 40, 5-34. Retrieved from https://www.agegeografia.es/ojs/index.php/bage/article/view/2007/1920

OECD (2015). Organization for Economic Cooperation and Development data. Retrieved from hitps://data.oecd.org

Parreño-Castellano, J. M., \& Domínguez-Mujica, J. (2008). Extranjería y diferenciación residencial en Canarias: la perspectiva del microanálisis espacial. Investigaciones Geográficas, 45, 163-199. htp://dx.doi.org/10.14198/INGEO2008.45.07

Parreño-Castellano, J., Domínguez-Mujica, J., Armengol-Martín, M. T., Pérez García, T., \& Boldú Hernández, J. (2018). Foreclosures and Evictions in Las Palmas de Gran Canaria during the Economic Crisis and Post-Crisis Period in Spain. Urban Science, 2(4), 109. http://dx.doi.org/10.3390/urbansci2040109

Raya, J.M. (2017). The determinants of foreclosures: Evidence from the Spanish case. Papers in Regional Science. http://dx.doi.org/10.1111/pirs.12316

Reglamento 2/2010, sobre criterios generales de homogeneización de las actuaciones de los servicios comunes procesales según Acuerdo de 25 de febrero de 2010, del Pleno del Consejo General del Poder Judicial. Publicado en el Boletín Oficial del Estado núm. 62, de 12 de marzo de 2010, páginas 24792 a 24811. Retrieved from https://boe.es/buscar/doc.php?id=BOE-A-2010$\underline{4127}$

Romero, J. (2010). Construcción residencial y gobierno del territorio en España. De la Burbuja especulativa a la recesión. Causas y consecuencias. Cuadernos Geográficos, 47, 17-46. 
Romero, J., Jiménez, F., \& Villoria, M. (2012). (Un) sustainable territories: causes of the speculative bubble in Spain (1996-2010) and its territorial, environmental, and sociopolitical consequences. Environment and Planning C: Government and Policy, 30, 467-486.

Sala, E. (2018). Crisis de la vivienda, movimientos sociales y empoderamiento: una revisión sistemática de la literatura. Documents d'Anàlisi Geogràfica, 64(1), 99-126. http://dx.doi.org/10.5565/rev/dag.379

Vives-Miró, S., González-Pérez, J. M., \& Rullan, O. (2015). Home dispossession: the uneven geography of evictions in Palma (Majorca). DIE ERDE-Journal of the Geographical Society of Berlin, 146(2-3), 113-126. http://dx.doi.org/10.12854/erde-146-10

Vives-Miró, S., \& Gutiérrez, A. (2017). Extracting rents through foreclosures: The rescue of Catalunya Banc as a new urban strategy following the burst of the Spanish bubble. Miscellanea Geographica, 21(4), 151-159. http://dx.doi.org/10.1515/mgrsd-2017-0030

Vives-Miró, S., \& Rullan, O. (2017). ¿Desposesión de vivienda por turistización? Revalorización y desplazamientos en el Centro Histórico de Palma (Mallorca). Revista de Geografía Norte Grande, 67, 53-71. http://dx.doi.org/10.4067/S0718-34022017000200004

Vives-Miró, S., Rullan, O., \& González-Pérez, J. M. (2017). Consecuencias sociales del modelo económico basado en el crédito. Geografía de las ejecuciones hipotecarias. Scripta Nova, XXI(553). http://dx.doi.org/10.1344/sn2017.21.17363

Walks, A. (2013). Mapping the urban debtscape: the geography of household debt in Canadian cities. Urban Geography, 34(2), 153-187. http://dx.doi.org/10.1080/02723638.2013.778647 